\title{
Global Accountability of Transnational Corporations: The UN Global Compact as a Global Norm
}

\author{
Mariko Shoji*
}

\begin{abstract}
The nature of the UN Global Compact has been studied from the perspective of three frameworks. The first is the theory of norm. The UNGC involves the creation of a network beyond transnational advocacy, as a transnational norm. The network of the UNGC is a public space for dialogue among participants. The second is the theory of subject. In the process of Multi-Stakeholder Initiatives, ownership of various stakeholders and actors including companies are discussed. Furthermore, it attempts to draw the sense of ownership and commitment from those who cannot recognize their ownership. The third is the theory of responsibility. In the age of globalization, in association with increasing multilateral actors, the concept of 'responsibility' should be multilayered. The concept of 'responsibility' should be interpreted stereoscopically and it will be necessary to understand and conceptualize many related concepts concerning 'accountability' such as 'responsibility,' 'charge' and 'commitment,' with gradations.
\end{abstract}

\section{Keywords}

UN Global Compact, CSR, GCJN, Norm, Soft Law, Responsibility, COPs

* Professor of Keiai University School of International Studies, Japan; Executive board member of the Japan Association of Global Governance; A member of the expert meeting of "Business for Peace" of the UN Global Compact. M.A. (Tsuda College). ORCID: http://orcid.org/0000-0003-1454-4941. The author may be contacted at: marisht@gmail.com / Address: Keiai University, Inage Campus, 1-5-21 Anagawa, Inage-ku, Chiba-shi, Chiba 263-8588 JAPAN. 


\section{Introduction}

The United Nations has contributed to 'norm setting' in the international society since its establishment. There are many kinds of positive norms which were supported in creation by the UN, such as multinational treaties, resolutions of the General Assembly and the Security Council, organizational rules, Memorandums of Understanding, Declarations, etc. All of these norms are not necessarily positive international laws which are concluded by sovereign States with legal binding force. In the international society, however, there are a variety of norms which are considered softer than international law. The United Nations Global Compact ("UNGC") is one of such norms adopted by the UN. The UNGC was proposed by the former UN Secretary General Kofi Annan and officially established at the UN Headquarters in New York on July 25, 2000. Its main purpose is to promote the Corporate Social Responsibility (“CSR"). The UNGC is a strategic policy initiative for businesses, committed to aligning their operations and strategies with ten universally accepted principles ${ }^{1}$ in the areas of human rights, labor, environment and anti-corruption. It can also be called soft law.

The UNGC is different features from positive international law in three distinct

1 UNGC, Ten Principles, available at https://www.unglobalcompact.org/AboutTheGC/TheTenPrinciples/index.html (last visited on Apr. 24, 2015). The UN Global Compact asks companies to embrace, support and enact, within their sphere of influence, a set of core values in the areas of human rights, labor standards, the environment and anti-corruption:

Human Rights

Principle 1: Businesses should support and respect the protection of internationally proclaimed human rights; and

Principle 2: make sure that they are not complicit in human rights abuses.

Labour

Principle 3: Businesses should uphold the freedom of association and the effective recognition of the right to collective bargaining;

Principle 4: the elimination of all forms of forced and compulsory labor;

Principle 5: the effective abolition of child labor; and

Principle 6: the elimination of discrimination in respect of employment and occupation.

Environment

Principle 7: Businesses should support a precautionary approach to environmental challenges;

Principle 8 : undertake initiatives to promote greater environmental responsibility; and

Principle 9: encourage the development and diffusion of environmentally friendly technologies.

Anti-Corruption

Principle 10: Businesses should work against corruption in all its forms, including extortion and bribery. 